\title{
New species and records of Dictyocheirospora from submerged wood in north-western Yunnan, China
}

\author{
Ru-Xiao Wang ${ }^{1,2 \dagger}$, Zong-Long Luo $^{2,3 \dagger}$, Kevin D. Hyde ${ }^{3}$, Jayarama D. Bhat ${ }^{4}$, Xi- \\ Jun $\mathrm{Su}^{2} \&$ Hong-Yan $\mathrm{Su}^{1 *, 2,5}$ \\ ${ }^{1}$ College of Basic Medicine, Dali University, Dali 671003, Yunnan, China \\ ${ }^{2}$ College of Agriculture \& Biological Sciences, Dali University, Dali 671003, Yunnan, China \\ ${ }^{3}$ Center of Excellence in Fungal Research, Mae Fah Luang University, Chiang Rai 57100, \\ Thailand \\ ${ }^{4}$ Formerly at Department of Botany, Goa University, Goa, 403206, India \\ ${ }^{\dagger}$ These authors have equally contributed to this paper.
}

Wang RX, Luo ZL, Hyde KD, Bhat DJ, Su XJ, Su HY 2016 -New species and records of Dictyocheirospora from submerged wood in north-western Yunnan, China. Mycosphere 7(9), 1357-1367, Doi 10.5943/mycosphere/7/9/9

\begin{abstract}
Two new species of Dictyocheirospora, D. aquatica and D. garethjonesii, isolated from submerged wood in aquatic habitats in north-western Yunnan, China, are introduced in this paper. The introductions are based on morphology and molecular analysis of DNA sequence data. We also recovered two fresh isolates of Dictyocheirospora rotunda D' Souza, Bhat \& K.D. Hyde, which is a first record for China. Descriptions and illustrations of D. aquatica, D. garethjonesii and D. rotunda are provided. The phylogenetic analysis of combined ITS and LSU sequence data place the isolates within the family Dictyosporiaceae (Pleosporales). A synopsis of characters of the accepted species of Dictyocheirospora is provided.
\end{abstract}

Key words - Asexual morphs - Dictyosporiaceae - Phylogeny - Taxonomy

\section{Introduction}

The order Pleosporales has been of great research interest in recent years and has undergone considerable revision (Zhang et al. 2009, 2012, Hyde et al. 2013, Ariyawansa et al. 2015). Boonmee et al. (2016) introduced the family Dictyosporiaceae (Pleosporales) to accommodate most cheirosporous hyphomycete genera that are saprobes on decaying wood and plant debris in terrestrial and freshwater habitats. One of the diagnostic characteristics of Dictyosporiaceae is their multicellular cheiroid conidia, and these morphological features separate it from other families in the suborder Massarineae (Hyde et al. 2016a).

The genus Dictyocheirospora D' Souza, Bhat \& K.D. Hyde, introduced by Boonmee et al. (2016) with Dictyocheirospora rotunda D' Souza, Bhat \& K.D. Hyde as the type species, is characterized by dark sporodochial colonies that produce aero-aquatic, cheiroid, dictyosporous conidia (Boonmee et al. 2016). Presently, there are seven species accepted in the genus.

We are studying the freshwater lignicolous fungi in three rivers, viz. Jinsha, Lancang and Dulong, in north-western Yunnan Province, China (Hyde et al. 2016b, Luo et al. 2016). In this 
study, five fresh collections of cheirosporous hyphomycetous taxa were made from submerged wood. Descriptions and illustrations are provided for two new species, D. aquatica and D. garethjonesii and for D. rotunda, which is a new record for China.

\section{Material \& methods}

\section{Isolation and morphology}

Specimens of submerged decaying wood were collected from Jinsha, Lancang and Dulong rivers, in north-western Yunnan, China and brought to the laboratory in plastic bags. The samples were incubated in plastic boxes lined with moistened tissue paper at room temperature for one week and processed and examined following the methods described in Taylor \& Hyde (2003). Morphological observations were made using a Motic SMZ 168 Series stereomicroscope and photographed by an OLYMPUS BX51 microscope imaging system. The fungal structures were measured using Image-Pro-Express software.

Single spore isolations were made to obtain the pure cultures as described in Chomnunti et al. (2014). The cultures are deposited in Mae Fah Luang University Culture Collection (MFLUCC), Culture collection of Kunming Institute of Botany (KUMCC) and Dali University (DLUCC). Herbarium specimens are deposited at the herbarium of Mae Fah Luang University (MFLU), the Herbarium of Cryptogams Kunming Institute of Botany Academia Sinica (HKAS) and Dali University (DLU). Facesoffungi and Index Fungorum numbers were obtained as in Jayasiri et al. (2015) and Index Fungorum (2016).

\section{DNA extraction, PCR amplification and sequencing}

Total genomic DNA was extracted from fresh fungal mycelium grown on PDA at room temperature. The EZ geneTM Fungal gDNA kit (GD2416) was used to extract DNA according to the manufacturer's instructions. ITS and LSU gene regions were amplified using the primer pairs ITS5/ITS4 and LROR/LR5. The final volume of the PCR reaction was $25 \mu \mathrm{L}$ and contained 12.5 $\mu \mathrm{L}$ of $2 \times$ Power Taq PCR MasterMix (a premix and ready to use solution, including $0.1 \mathrm{Units} / \mu \mathrm{L}$ Taq DNA Polymerase, $500 \mu \mathrm{M}$ dNTP Mixture each (dATP, dCTP, dGTP, dTTP), $20 \mathrm{mM}$ Tris$\mathrm{HCl} \mathrm{pH} 8.3,100 \mathrm{mM} \mathrm{KCl}, 3 \mathrm{mM} \mathrm{MgCl} 2$, stabilizer and enhancer $), 1 \mu \mathrm{L}$ of each primer $(10 \mu \mathrm{M}), 1$ $\mu \mathrm{L}$ genomic DNA extract and $9.5 \mu \mathrm{L}$ deionised water. The PCR thermal cycleprogram for ITS amplification was as follows: initially $95{ }^{\circ} \mathrm{C}$ for 3 minutes, followed by 35 cycles of denaturation at $95{ }^{\circ} \mathrm{C}$ for 1 minutes, annealing at $53{ }^{\circ} \mathrm{C}$ for 30 seconds, elongation at $72{ }^{\circ} \mathrm{C}$ for $1 \mathrm{~min}$. The PCR thermal cycle program for LSU was followed as initially $95{ }^{\circ} \mathrm{C}$ for 3 minutes, followed by 35 cycles of denaturation at $95{ }^{\circ} \mathrm{C}$ for 30 seconds, annealing at $52{ }^{\circ} \mathrm{C}$ for 40 seconds, elongation at 72 ${ }^{\circ} \mathrm{C}$ for 90 seconds. PCR products were purified using minicolumns, purification resin and buffer according to the manufacturer's protocols (Amershamproduct code: 27-9602-01). The sequences were carried by Beijing Tsingke Biological Engineering Technology and Services Co., Ltd (Beijing, P.R. China).

\section{Phylogenetic analysis}

Raw sequences were assembled with Sequencher 4.9 for Windows (Gene Codes Corp., Ann Arbor, Michigan). The consensus sequences were initially aligned using MAFFTv.7 (http://mafft.cbrc.jp/alignment/server/) (Katoh \& Standley 2013) and optimised manually when needed.

A Maximum likelihood (ML) analysis was performed using RAxMLGUI v. 1.3 (Silvestro \& Michalak 2011). The optimal ML tree search was conducted with 1000 separate runs, using the default algorithm of the program from a random starting tree for each run. The final tree was selected among suboptimal trees from each run by comparing likelihood scores under the GTR+GAMMA substitution model. Maximum parsimony analyses were performed using the heuristic search option with 1000 random taxa additions and tree bisection and reconnection (TBR) as the branch-swapping algorithm. All characters were unordered and of equal weight and gaps 
were treated as missing data. Maxtrees were unlimited, branches of zero length were collapsed and all multiple, equally parsimonious trees were saved. Clade stability was assessed using a bootstrap (BT) analysis with 1000 replicates, each with 10 replicates of random stepwise addition of taxa (Hillis \& Bull 1993).

Bayesian analyses were performed by using PAUP v.4.0b10 (Swofford 2002) and MrBayes v3.1.2 (Ronquist \& Huelsenbeck 2003). The model of evolution was estimated by using MrModeltest 2.2 (Nylander 2004). Posterior probabilities (PP) (Rannala \& Yang 1996) were performed by Markov Chain Monte Carlo Sampling (BMCMC) in MrBayes v. 3.0b4 (Liu et al. 2012). Six simultaneous Markov Chains were run for 1 million generations and trees were sampled every 100th generation (Resulting 10000 total trees) (Cai et al. 2006). The first 2000 trees representing the burn-in phase of the analyses were discarded and the remaining 8000 (post burning) trees used for calculating posterior probabilities (PP) in the majority rule consensus tree (Cai et al. 2006, Liu et al. 2012 ).

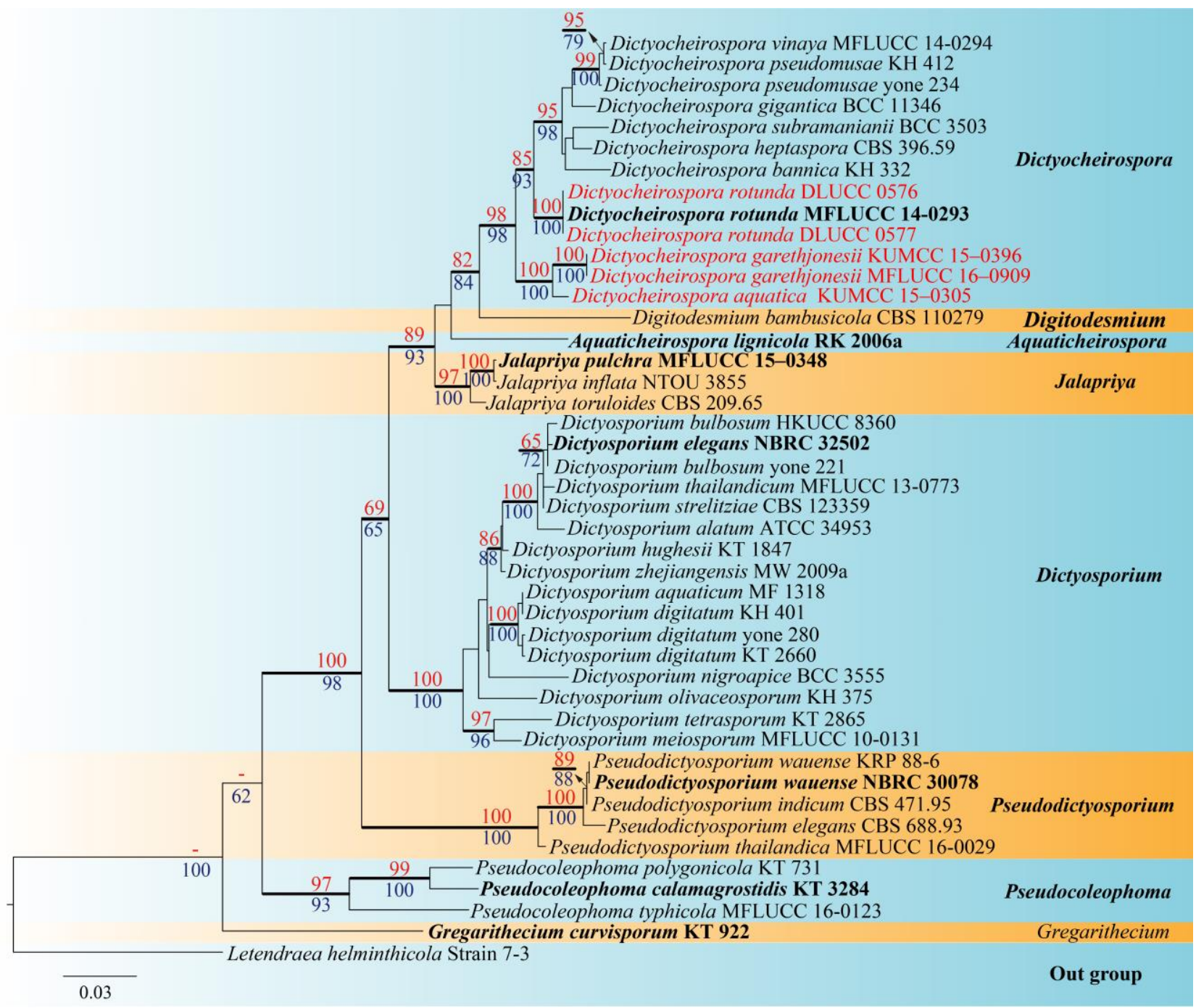

Fig. 1 Phylogram generated from Maximum likelihood analysis (RAxML) based on combined ITS and LSU sequence data for the family Dictyosporiaceae. Bootstrap support values for maximum likelihood (red) equal to or greater than $60 \%$ are given above the nodes. Bootstrap support values for maximum parsimony (blue) equal to or greater than $60 \%$ are given below the nodes. Branches with Bayesian posterior probabilities greater than 0.95 are in bold. The tree is rooted to Letendraea helminthicola (strain 7-3). Newly generated sequences are indicated in red and generic types are highlighted in bold. 
The phylogenetic analyses were carried out with combined ITS and LSU sequence data alignment to illustrate the placement of the isolates in Tubeufiaceae. All new sequence data generated in this study are deposited in GenBank (Table 1). All alignments are deposited in TreeBASE (www.treebase.org, submission number 20337). Phylogenetic trees were viewed in Treeview (Page 1996). The terminals of the tree (Fig. 1) are labelled with species and the isolates/culture collection codes as provided in GenBank.

Table: 1 Isolates and sequences used in this study (newly generated sequences are indicated in bold, ex-type strains are indicated in $*$ after collection number).

\begin{tabular}{|c|c|c|c|}
\hline \multirow{2}{*}{ Species } & \multirow{2}{*}{ Collection/Isolate No. } & \multicolumn{2}{|c|}{ GenBank Accession No. } \\
\hline & & ITS & LSU \\
\hline Aquaticheirospora lignicola & RK 2006a* & AY864770 & AY736378 \\
\hline Dictyocheirospora aquatica & KUMCC 15-0305* & KY320508 & KY320513 \\
\hline Dictyocheirospora bannica & KH 332 & LC014543 & AB807513 \\
\hline Dictyocheirospora garethjonesii & MFLUCC 16-0909* & KY320509 & KY320514 \\
\hline Dictyocheirospora garethjonesii & KUMCC 15-0396 & KY320510 & KY320515 \\
\hline Dictyocheirospora gigantica & BCC 11346 & DQ018095 & - \\
\hline Dictyocheirospora heptaspora & CBS 396.59 & DQ018090 & - \\
\hline Dictyocheirospora rotunda & MFLUCC 14-0293* & KU179099 & KU179100 \\
\hline Dictyocheirospora rotunda & DLUCC 0576 & KY320511 & KY320516 \\
\hline Dictyocheirospora rotunda & DLUCC 0577 & KY320512 & KY320517 \\
\hline Dictyocheirospora vinaya & MFLUCC 14-0294* & KU179102 & KU179103 \\
\hline Dictyocheirospora pseudomusae & KH 412 & LC014549 & AB807516 \\
\hline Dictyocheirospora pseudomusae & yone $234^{*}$ & LC014550 & AB807520 \\
\hline Dictyocheirospora subramanianii & BCC 3503 & DQ018094 & - \\
\hline Dictyosporium alatum & ATCC34953* & NR077171 & DQ018101 \\
\hline Dictyosporium aquaticum & MF1318* & KM610236 & - \\
\hline Dictyosporium bulbosum & HKUCC 8360 & DQ018086 & - \\
\hline Dictyosporium bulbosum & yone 221 & LC014544 & AB807511 \\
\hline Dictyosporium digitatum & KH 401 & LC014545 & AB807515 \\
\hline Dictyosporium digitatum & KT 2660 & LC014546 & AB807518 \\
\hline Dictyosporium digitatum & yone 280 & LC014547 & AB807512 \\
\hline Dictyosporium elegans & NBRC $32502^{*}$ & DQ018087 & DQ018100 \\
\hline Dictyosporium hughesii & KT 1847 & LC014548 & AB807517 \\
\hline Dictyosporium meiosporum & MFLUCC 10-0131* & KP710944 & KP710945 \\
\hline Dictyosporium nigroapice & BCC 3555 & DQ018085 & - \\
\hline Dictyosporium olivaceosporum & KH 375 & LC014542 & AB807514 \\
\hline Dictyosporium strelitziae & CBS $123359^{*}$ & FJ839618 & FJ839653 \\
\hline Dictyosporium tetrasporum & KT 2865 & LC014551 & AB807519 \\
\hline Dictyosporium thailandicum & MFLUCC 13-0773* & KP716706 & KP716707 \\
\hline Dictyosporium zhejiangensis & MW-2009a & FJ456893 & - \\
\hline Digitodesmium bambusicola & CBS $110279^{*}$ & DQ018091 & DQ018103 \\
\hline Gregarithecium curvisporum & KT $922^{*}$ & AB809644 & AB807547 \\
\hline Jalapriya inflata & NTOU 3855 & JQ267362 & JQ267363 \\
\hline Jalapriya pulchra & MFLUCC 15-0348 & KU179108 & KU179109 \\
\hline Jalapriya toruloides & CBS 209.65 & DQ018093 & DQ018104 \\
\hline Letendraea helminthicola & Strain 7-3 & HM486428 & AY016362 \\
\hline Pseudocoleophoma calamagrostidis & KT $3284^{*}$ & LC014592 & LC014609 \\
\hline Pseudocoleophoma polygonicola & KT $731^{*}$ & AB809634 & AB807546 \\
\hline Pseudocoleophoma typhicola & MFLUCC 16-0123* & KX576655 & KX576656 \\
\hline Pseudodictyosporium elegans & CBS 688.93* & DQ018099 & DQ018106 \\
\hline Pseudodictyosporium indicum & CBS 471.95 & DQ018097 & - \\
\hline Pseudodictyosporium thailandica & MFLUCC 16-0029* & KX259520 & KX259522 \\
\hline Pseudodictyosporium wauense & NBRC 30078 & DQ018098 & DQ018105 \\
\hline Pseudodictyosporium wauense & KRP88-6 & HМ036613 & - \\
\hline
\end{tabular}

\section{Results \\ Phylogenetic analyses}


ITS and LSU sequence data were used to resolve the generic placement of the collections of Dictyosporiaceae. The alignment datasets included 44 taxa of which Letendraea helminthicola (strain 7-3) was used as the outgroup taxon. The combined datasets comprised 1265 characters including gaps. The best scoring RAxML tree was chosen as the backbone tree and is shown in Fig. 1.

The phylogenetic analyses show that all the new strains cluster in the genus Dictyocheirospora with high support (98\% ML, 98\% MP and 1.00 PP). Two isolates clustered with Dictyocheirospora rotunda with 100\% ML, 100\% MP and 1.00 PP. Three new isolates formed a distinct clade at the basal position of the genus Dictyocheirospora with strong support (100\% ML, 100\% MP and 1.00 PP), but Dictyocheirospora garethjonesii (MFLUCC 16-0909 and KUMCC 15-0396) clustered with $D$. aquatica (KUMCC 15-0305) in a sister group.

\section{Taxonomy}

Dictyocheirospora aquatica Z.L. Luo, D.J. Bhat \& K.D. Hyde, sp. nov.

Index Fungorum number: IF 552683; Facesoffungi number: FoF 02733; Fig. 2

Etymology - Referring to aquatic habitat of this fungus.

Holotype - HKAS 92714

Saprobic on decaying, submerged wood in freshwater. Sexual morph: Undetermined. Asexual morph: Hyphomycetous. Colonies on natural substrate superficial, scattered. Mycelium immersed, composed of pale brown, smooth, septate, branched hyphae. Conidiomata sporodochial, 150-250 $\mu \mathrm{m}$ wide, dark brown to black. Conidiophores micronematous, undifferentiated from vegetative hyphae, short. Conidiogenous cells holoblastic, integrated, terminal, pale brown, smooth-walled. Conidia 34-42 × 12.5-19.5 $\mu \mathrm{m}(\bar{x}=38 \times 16 \mu \mathrm{m}, \mathrm{n}=35)$, solitary, acrogenous, cheiroid, pale brown to brown, consisting of 5-6 rows of cells, with rows cylindrical, palmately divergent, inwardly curved at the tip, arising from a basal cell, without appendages, with each row composed of 8-10 cells, euseptate, slightly constricted at septa, smooth-walled.

Material examined - CHINA, Yunnan Province, Dulong River, on decaying submerged wood, 6 May 2015, Z.L. Luo, S-395 (HKAS 92714, holotype); ex-type living culture, KUMCC 15-0305.

Notes - Dictyocheirospora aquatica morphologically resembles D. subramanianii in having a similar conidial size and cylindrical, palmately divergent rows of cells, without appendages. However, $D$. aquatica differs from $D$. subramanianii in conidial shape with 5-6 separable rows, having 6-8 cells in each row, whereas the conidia in the latter has seven tightly appressed rows with each having 9-13 cells (Sutton 1985). Phylogenetic analysis also showed that D. aquatica is distinct from $D$. subramanianii (Fig. 1).

Dictyocheirospora garethjonesii Z.L. Luo, H.Y. Su \& K.D. Hyde, sp. nov.

Index Fungorum number: IF 552684; Facesoffungi number: FoF 02734; Fig. 3

Etymology - In honour of Professor E.B.G. Jones for his major contributions to mycology.

Holotype - HKAS 92836

Saprobic on decaying, submerged wood in freshwater. Sexual morph: Undetermined. Asexual morph: Hyphomycetous. Colonies on natural substrate superficial, scattered. Mycelium immersed, composed of brown, smooth, septate hyphae. Conidiomata sporodochial, dark brown, 200-300 $\mu \mathrm{m}$ wide. Conidiophores micronematous, undifferentiated from vegetative hyphae, short. Conidiogenous cells holoblastic, integrated, terminal, pale brown, cylindrical, smooth-walled. Conidia 45.5-54.5 $\times 15.5-24.5 \mu \mathrm{m}(\bar{x}=50 \times 20 \mu \mathrm{m}, \mathrm{n}=25)$, solitary, acrogenous, cheiroid, brown, consisting of 6-7 rows of cells, with rows digitate, cylindrical, inwardly curved at apex, arising from a basal cell, without appendages, with each row composed of 7-10 cells, euseptate, slightly constricted at septa.

Material examined - CHINA, Yunnan Province, Lancang River, on submerged wood, 25 April 2015, Z.L. Luo, S-310 (HKAS 92836, holotype), ex-type living culture MFLUCC 16-0909; 
ibid. Jinsha River, on submerged wood, 18 April 2015, S.M. Tang, S-422 (DLU 0422 ); living culture, KUMCC 15-0396.

Notes - Dictyocheirospora garethjonesii is morphologically similar to $D$. rotunda and $D$. aquatica. However, D. garethjonesii differs from $D$. rotunda in having conidia with 6-7 rows with each row composed of 7-10 cells, whereas the conidia of $D$. rotunda have 5-7 rows with each row composed of 8-12 cells (Boonmee et al. 2016). Dictyocheirospora garethjonesii differs from D. aquatica in having larger conidia $(45.5-54.5 \times 15.5-24.5 \mu \mathrm{m}$ vs $34-42 \times 12.5-19.5 \mu \mathrm{m})$ and conidia with 6-7 rows and each row composed of 7-10 cells, whereas the conidia of $D$. aquatica have 5-6 rows and each row composed of 6-8 cells (Table 2). Phylogenetic analysis also showed that $D$. garethjonesii is distinct from D. subramanianii (Fig. 1).
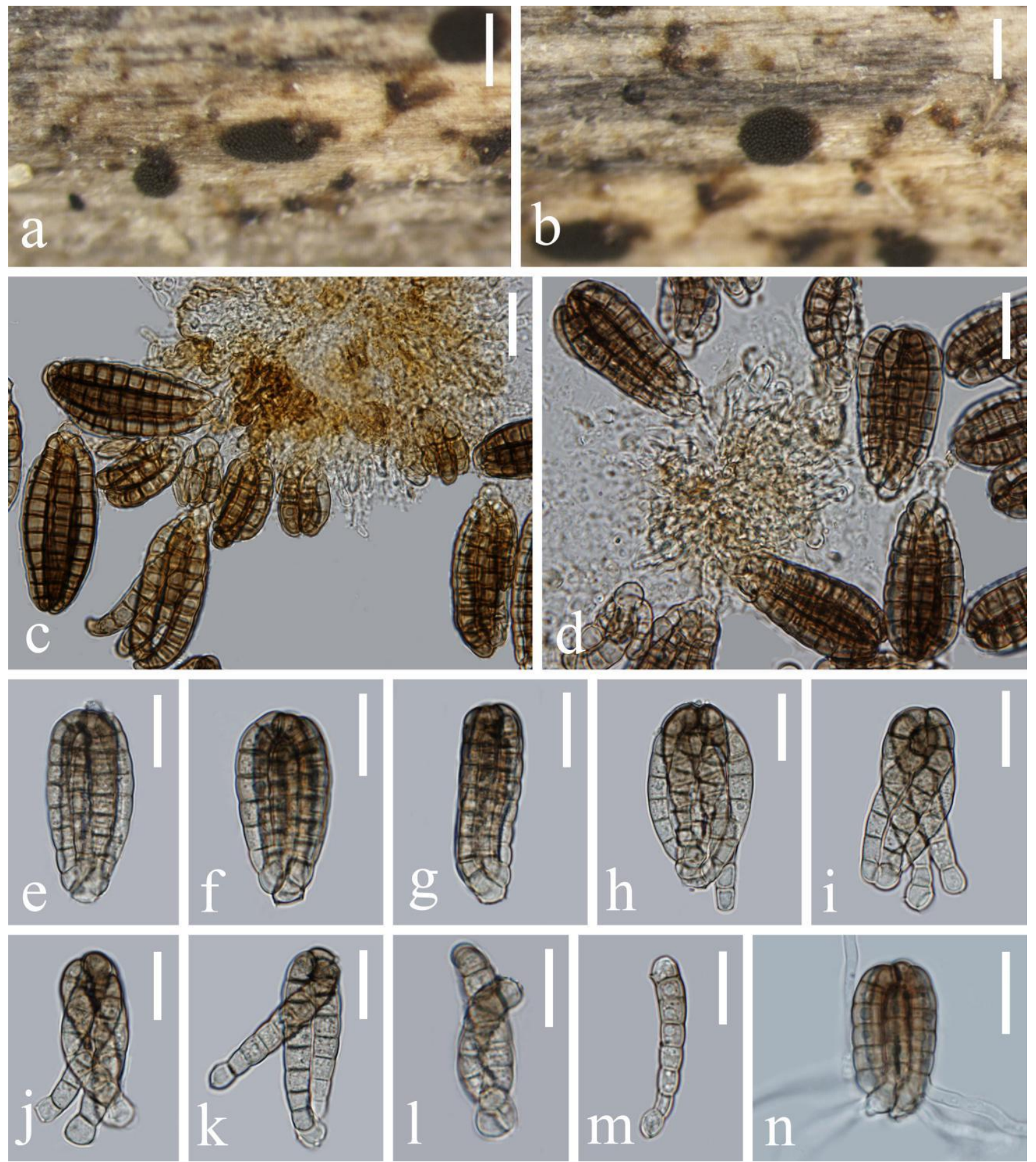

Fig. 2 - Dictyocheirospora aquatica (HKAS 92714, holotype) a-b Conidiomata on the substrate. c-d Squash mount of conidioma with conidiogenous cells. e-g Conidia. $\mathbf{h}-\mathbf{m}$ Separable rows. $\mathbf{n}$ Germinating conidium. - Scale bars: a-b $=200 \mu \mathrm{m}, \mathbf{c}-\mathbf{d}=20 \mu \mathrm{m}, \mathbf{e}-\mathbf{n}=10 \mu \mathrm{m}$. 

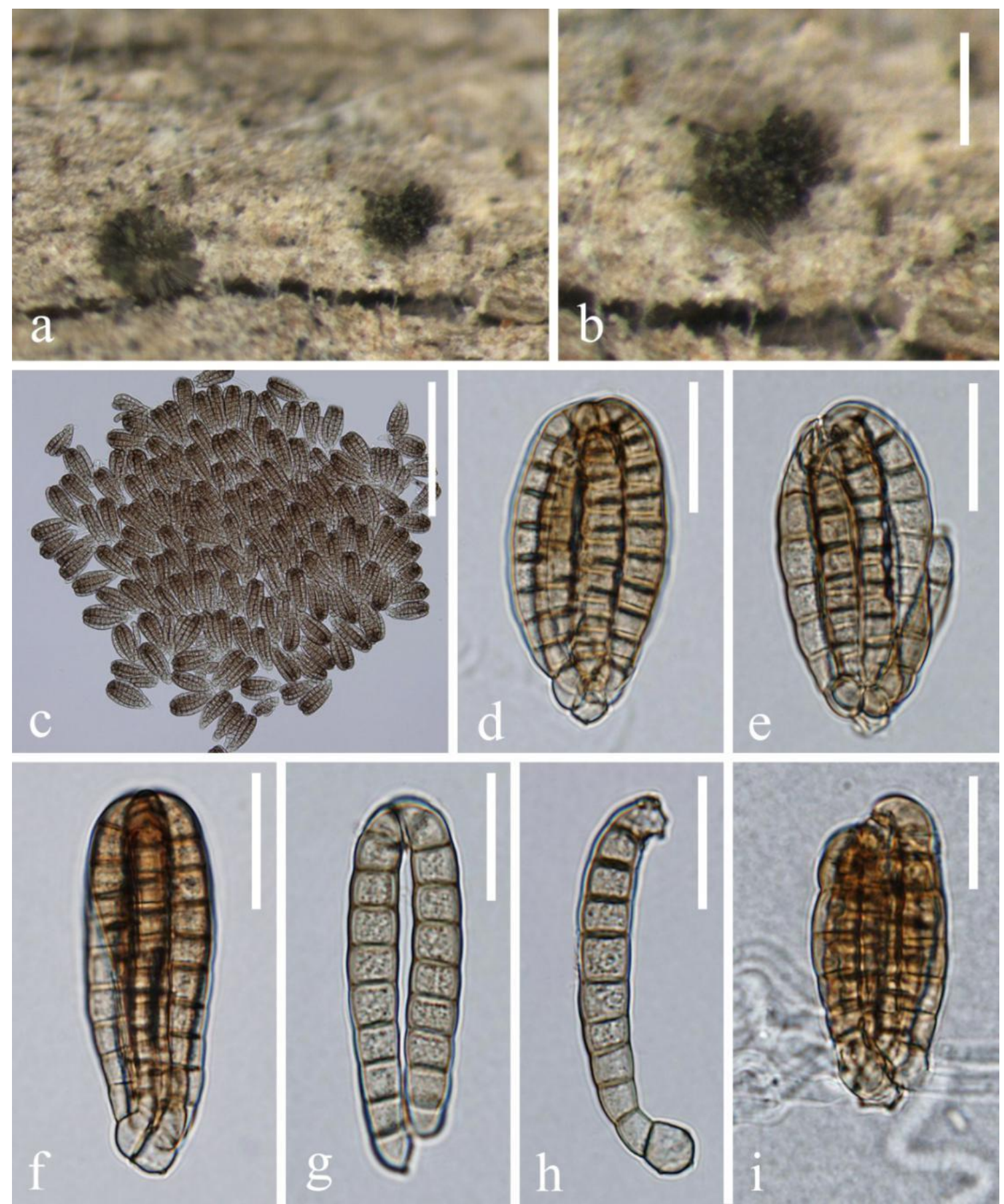

Fig. 3 - Dictyocheirospora garethjonesii (HKAS 92836, holotype) a-b Colonies on the substrate. c Squash mount of conidia. d-f Conidia. $\mathbf{g}-\mathbf{h}$ Crushed conidia. $\mathbf{i}$ Germinating conidium. - Scale bars: $\mathbf{b}=250 \mu \mathrm{m}, \mathbf{c}=150 \mu \mathrm{m}, \mathbf{d}-\mathbf{i}=20$ $\mu \mathrm{m}$.

Dictyocheirospora rotunda D’Souza, D.J. Bhat \& K.D. Hyde, Fungal Diversity 80: 465

Facesoffungi number: FoF 01262; Fig. 4

Saprobic on decaying, submerged wood in freshwater. Sexual morph: Undetermined. Asexual morph: Hyphomycetous. Colonies on natural substrate scattered. Mycelium immersed, composed of brown, smooth, septate hyphae. Conidiomata sporodochial, dark brown to black, 150$250 \mu \mathrm{m}$. Conidiophores micronematous, pale brown, smooth. Conidiogenous cells holoblastic, integrated, terminal, pale brown, cylindrical, smooth-walled. Conidia 49-55 $\times 19.5-22.5 \mu \mathrm{m}(\bar{x}=$ $52 \times 21 \mu \mathrm{m}, \mathrm{n}=35$ ), solitary, acrogenous, cheiroid, pale brown to brown, consisting of 5-7 rows of cells, rows digitate, cylindrical, inwardly curved at the tip, arising from a basal cell, without 
appendages, with each row composed of 8-12 cells, euseptate, guttulate, slightly constricted at septa.

Material examined - CHINA, Yunnan Province, Jinsha River, on submerged wood, 19 April 2015, Z.L. Luo, JSJ H 11-7-1 (HKAS 92883), living culture, DLUCC 0576; ibid. 21 April 2015, Q Dai, JSJ H 35-1-1 (HKAS 92994), living culture, DLUCC 0577.

Notes - Dictyocheirospora rotunda, the type species of Dictyocheirospora, was introduced by Boonmee et al. (2016). Two new collections were from submerged wood in Jinsha River, during our study of lignicolous freshwater fungi of three parallel rivers in northwestern Yunnan Province, China. Morphologically our fresh collections fit perfectly well with the description of Dictyocheirospora rotunda (Boonmee et al. 2016). The phylogenetic analyses of our strains (DLUCC 0576 and DLUCC 0577) clustered with D. rotunda with high bootstrap support (100\% ML, 100\% MP and 1.00 PP).
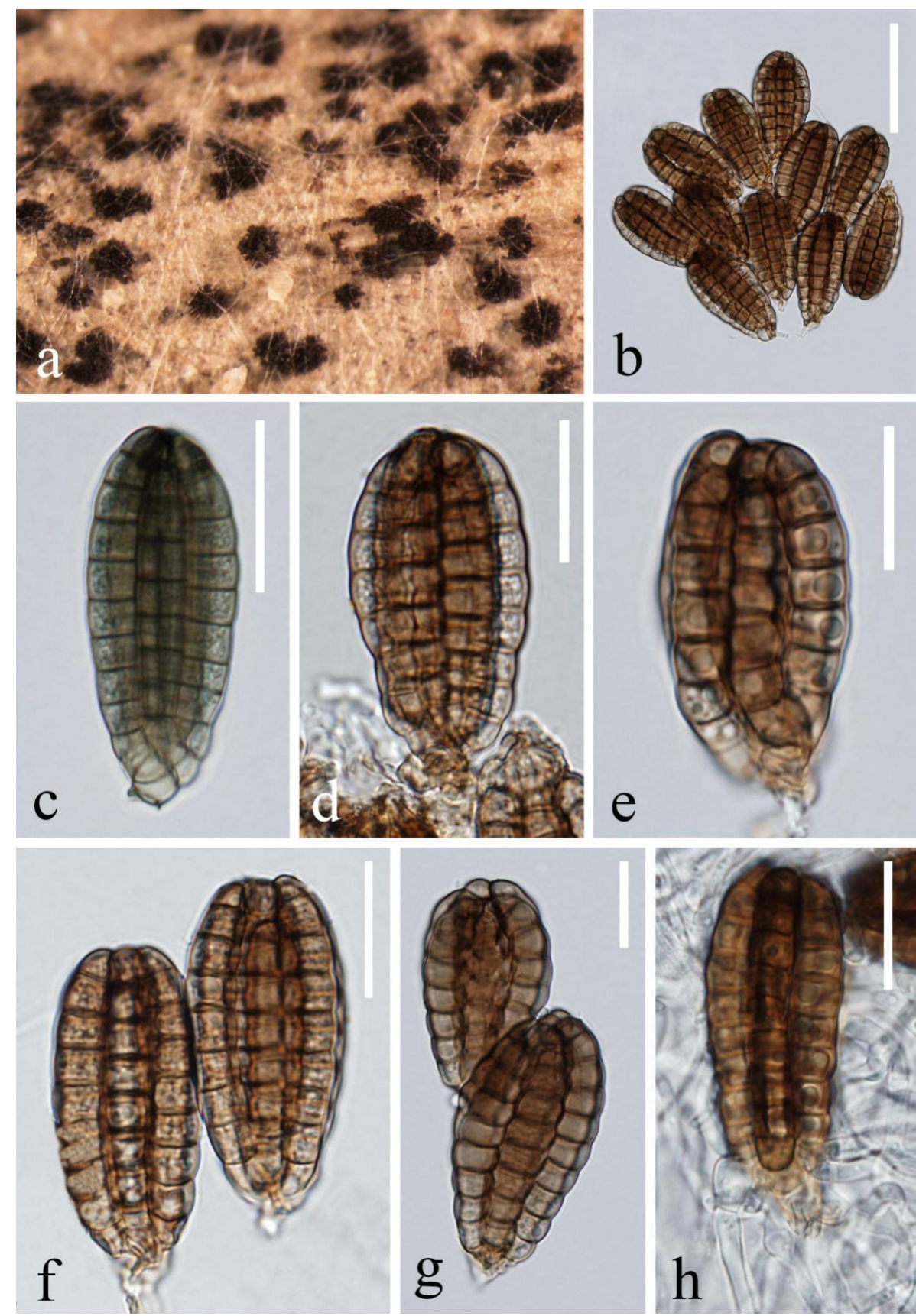

Fig. 4 -Dictyocheirospora rotunda (HKAS 92883) a Conidiomata on the substrate. b Squash mount of conidioma. cg Conidia. h Germinating conidium. - Scale bars: $\mathbf{b}=50 \mu \mathrm{m} ; \mathbf{c}-\mathbf{h}=20 \mu \mathrm{m}$. 
Table 2. A synopsis of characters of Dictyocheirospora species

\begin{tabular}{|c|c|c|c|c|c|c|c|}
\hline \multirow[b]{2}{*}{ Species } & \multirow[b]{2}{*}{ Colonies } & \multicolumn{4}{|c|}{ Conidia } & \multirow[b]{2}{*}{ Substrate } & \multirow[b]{2}{*}{ Reference } \\
\hline & & Size $(\mu \mathrm{m})$ & Shape & No. of rows & $\begin{array}{c}\text { No. of cells } \\
\text { with each } \\
\text { row }\end{array}$ & & \\
\hline $\begin{array}{l}\text { Dictyocheirospora } \\
\text { aquatica }\end{array}$ & Sporodochial & $\begin{array}{c}34-42 \times \\
12.5-19.5 \\
\end{array}$ & Cylindrical & $5-6$ & $6-8$ & Submerged decaying wood & This study \\
\hline D. bannica & Punctiform & $\begin{array}{c}73-86 \times \\
21-26\end{array}$ & $\begin{array}{l}\text { Ellipsoid to } \\
\text { cylindrical }\end{array}$ & $(5-) 7$ & $17-19$ & $\begin{array}{l}\text { Submerged twigs of woody } \\
\text { plant }\end{array}$ & $\begin{array}{l}\text { Boonmee et } \\
\text { al. } 2016\end{array}$ \\
\hline D. garethjonesii & Sporodochial & $\begin{array}{c}45.5-54.5 \times \\
15.5-24.5\end{array}$ & Cylindrical & $6-7$ & $7-10$ & Submerged decaying wood & This study \\
\hline D. gigantica & Sporodochial & $\begin{array}{c}105-121 \times \\
25-32\end{array}$ & Cylindrical & 7 & $19-22$ & Submerged decaying wood & $\begin{array}{l}\text { Goh et al. } \\
1999\end{array}$ \\
\hline D. heptaspora & Sporodochial & $\begin{array}{c}50-80 \times \\
20-30 \\
\end{array}$ & Cylindrical & 7 & $\begin{array}{c}\text { No } \\
\text { available }\end{array}$ & Palm and submerged wood & $\begin{array}{c}\text { Goh et al. } \\
1999\end{array}$ \\
\hline D. rotunda & Sporodochial & $\begin{array}{c}42-58 \times \\
19-38\end{array}$ & Cylindrical & $5-7$ & $8-12$ & Submerged decaying wood & $\begin{array}{c}\text { Tanaka et al } \\
2015\end{array}$ \\
\hline D. rotunda & Sporodochial & $\begin{array}{c}49-55 \times \\
19.5-22.5\end{array}$ & Cylindrical & $5-7$ & $8-12$ & Submerged decaying wood & This study \\
\hline D. pseudomusae & Sporodochial & $\begin{array}{c}61-78 \times \\
19-29\end{array}$ & $\begin{array}{l}\text { Ellipsoid to } \\
\text { cylindrical }\end{array}$ & $(6-) 7$ & $13-15$ & $\begin{array}{l}\text { Submerged dead twigs of } \\
\text { Bamboo }\end{array}$ & $\begin{array}{c}\text { Tanaka et al } \\
2015\end{array}$ \\
\hline D. subramanianii & Sporodochial & $\begin{array}{c}33-42 \times \\
16-20\end{array}$ & Cylindrical & 7 & $9-13$ & Palm & Sutton 1985 \\
\hline D. vinaya & Sporodochial & $\begin{array}{c}58-67 \times \\
15.5-26.5\end{array}$ & Cheiroid & $6-7$ & $9-13$ & Submerged decaying wood & $\begin{array}{l}\text { Boonmee et } \\
\text { al. } 2016\end{array}$ \\
\hline
\end{tabular}




\section{Discussion}

Freshwater taxa forming on the surface of wood, with multicellular, cheiroidconidia produced in sporodochia, were previously placed in the genus Dictyosporium. This fungal form is common in freshwater streams and swamps worldwide (Pinruan et al. 2007, Tsui et al. 2000, Ho et al. 2001, 2002). Boonmee et al. (2016), however revised the genus based on morphology and molecular analysis and accepted ten genera in Dictyosporiaceae. Dictyocheirospora is cosmopolitan in distribution and largely reported from freshwater habitats in Asia, Europe and Africa (Ellis 1971, Morris 1978, Mercado-Sierra 1981, Rao \& de Hoog 1986, Matsushima 1993, Goh et al. 1999, Boonmee et al. 2016). The fresh collections used in this study are from submerged wood in freshwater lotic habitats in northwestern Yunnan Province, China.

\section{Acknowledgments}

We would like to thank the National Natural Science Foundation of China (Project ID: 31460015, 31660008), Middle-Younger Academic Leaders of Candidates Projects in Yunnan Province (2012HB-042) and "Collaborative Innovation Center for Biodiversity and Conservation in the Three Parallel Rivers Region of China" for financial and laboratory support. Z.L. Luo thank Dr. Shaun Pennycook from Landcare Research, Auckland, New Zealand, for advising on the taxon name.

\section{References}

Ariyawansa HA, Phukhamsakda C, Thambugala KM, Bulgakov TS et al. 2015 - Revision and phylogeny of Leptosphaeriaceae. Fungal Diversity 74, 1-33.

Boonmee S, D'souza MJ, Luo ZL, Pinruan U et al. 2016 - Dictyosporiaceae fam. nov. Fungal Diversity 80, 457-482.

Cai L, Jeewon R, Hyde KD. 2006 - Phylogenetic investigations of Sordariaceae based on multiple gene sequences and morphology. Mycological Research 110, 137-150.

Chomnunti P, Hongsanan S, Aguirre-Hudson B, Tian Q et al. 2014 - The sooty moulds. Fungal Diversity 66, 1-36.

Ellis MB 1971 - Dematiaceous hyphomycetes. Commonwealth Mycological Institute, Kew.

Goh TK, Hyde KD, Ho WH, Yanna. 1999 - A revision of the genus Dictyosporium, with descriptions of three new species. Fungal Diversity 2, 65-100.

Hillis DM, Bull JJ. 1993 - An empirical test of bootstrapping as a method for assessing confidence in phylogenetic analysis. Systematic Biology 42, 182.

Ho WH, Hyde KD, Hodgkiss IJ, Yanna. 2001 - Fungal communities on submerged wood from streams in Brunei, Hong Kong and Malaysia. Mycological Research 105, 1492-1501.

Ho WH, Yanna, Hyde KD, Hodgkiss IJ. 2002 - Seasonality and sequential occurrence of fungi on wood submerged in Tai Po Kau Forest Stream, Hong Kong. Fungal Diversity 10, 21-43.

Hyde KD, Jones EBG, Liu JK, Ariyawansa H et al. 2013 - Families of Dothideomycetes. Fungal Diversity 63, 1-313.

Hyde KD, Hongsanan S, Jeewon R, Bhat DJ et al. 2016a - Fungal diversity notes 367-492: taxonomic and phylogenetic contributions to fungal taxa. Fungal Diversity 80, 1-270.

Hyde KD, Fryar S, Tian Q, Bahkali AH, Xu JC. 2016b - Lignicolous freshwater fungi along a north-south latitudinal gradient in the Asian/Australian region; can we predict the affects of global warming on biodiversity and function? Fungal Ecology 19, 190-200.

Jayasiri SC, Hyde KD, Ariyawansa HA, Bhat DJ et al. 2015 - The Faces of Fungi database: fungal names linked with morphology, phylogeny and human impacts. Fungal Diversity 74, 3-18.

Katoh K, Standley DM 2013 - MAFFT multiple sequence alignment software version 7: improvements in performance and usability. Molecular Biology \& Evolution 30, 772-780.

Liu JK, Phookamsak R, Doilom M, Wikee S et al. 2012 - Towards a natural classification of Botryosphaeriales. Fungal Diversity 57, 149-210 
Luo ZL, Bao DF, Bhat DJ, Yang J et al. 2016 - Sporoschisma from submerged wood in Yunnan, China. Mycological Progress 15, 1145-1155.

Matsushima T. 1993 - Matsushima Mycological Memoirs 7. Matsushima: Kobe, Japan. Mercado

Sierra A. 1981 - Lista preliminar de hifomicetes demaci, keos de la Estacion Ecologica de Sierra del Rosarioy zonas adyacentes. Acta Botanica Cubana 6, 1-6.

Morris EP. 1978 - Belizean hyphomycetes. Mycotaxon 7, 265-274.

Nylander JAA. 2004 - MrModeltest v2.2 Program distributed by the author. Evolutionary Biology Centre, Uppsala University, Uppsala

Page RD 1996 - TREEVIEW: an application to display phylogenetic trees on personal computers. Computer Applications in the Biosciences 12, 357-358.

Rannala B, Yang Z. 1996 - Probability distribution of molecular evolutionary trees: a new method of phylogenetic inference. Journal of Molecular Evolution 43, 304-311.

Rao V, Hoog GS de 1986 - New or critical hyphomycetes from India. Studies in Mycology 28, 184.

Ronquist F, Huelsenbeck JP. 2003 - MrBayes 3: Bayesian phylogenetic inference under mixed models. Bioinformatics 19, 1572.

Silvestro D, Michalak I. 2011 - RAxML-GUI: a graphical front-end for RAxML. Organisms Diversity \& Evolution 12, 335-337.

Sutton BC 1985 - Notes on some deuteromycete genera with cheiroid or digitate brown conidia. Proceedings of the National Academy of Sciences, India Section B 94, 229-244.

Swofford DL. 2002 - PAUP 4.0b10: phylogenetic analysis using parsimony. Sinauer Associates, Sunderland.

Tanaka K, Hirayama K, Yonezawa H, Sato G, Toriyabe A, Kudo H, Hashimoto A, Matsumura M, Harada Y, Kurihara Y, Shirouzu T, Hosoya T. 2015 - Revision of the Massarineae (Pleosporales, Dothideomycetes). Studies in Mycology 82, 75-136.

Taylor JE, Hyde KD. 2003 - Microfungi on Tropical and Temperate Palms. In: Fungal Diversity Research Series 12, 1-459.

Tsui CKM, Hyde KD, Hodgkiss IJ. 2000 - Biodiversity of fungi on submerged wood in Hong Kong streams. Aquatic Microbial Ecology 21, 289-298.

Zhang Y, Schoch CL, Fournier J, Crous PW et al. 2009 - Multi-locus phylogeny of Pleosporales: a taxonomic, ecological and evolutionary re-evaluation. Studies in Mycology 64, 85-102.

Zhang Y, Crous PW, Schoch CL, Hyde KD. 2012 - Pleosporales. Fungal Diversity 53, 1-221. 